\title{
Gambaran Skor INVR (Index of Nausea, Vomiting and Retching) pada CINV (Chemotherapy Induced Nausea and Vomiting) Kanker Payudara di RSUP M Djamil Padang
}

Wella Juartika1, Pramana Khalilul Harmi², Rika Fatmadona ${ }^{3}$

\begin{abstract}
Abstrak
Kanker payudara merupakan penyebab kematian tertinggi pada wanita. Tujuan: Menentukan gambaran skor INVR pad CINV pada kanker payudara di RSUP M.Djamil Padang. Metode: Penelitian ini merupakan studi deskriptif kuantitatif terhadap data rekam medis. Sampel penelitian sebanyak 19 pasien yang didiagnosis kanker payudara di Bagian Kemoterapi RSUP Dr. M. Djamil Padang tahun 2019. Hasil: Sebagian besar pasien adalah kelompok usia lansia awal (42,1\%), pendidikan tinggi $(68,4 \%)$, stadium $(63,4 \%)$ dan siklus kemoterapi ke $2(21,4 \%)$. Pengukuran rerata skor mual muntah di lakukan 72 jam atau 6 kali pengukuran. Rerata mual muntah pada kelompok intervensi tertinggi pada pengukuran 60 jam $(21,00)$ dengan nilai min-mak $(15-28)$ dan terendah pada pengukuran 72 jam $(18,00)$ dengan nilai min-mak (3-22). Simpulan: Pada skor INVR terjadi penurunan namun kembali terjadi kenaikan.
\end{abstract}

Kata kunci: CINV, INVR, kanker payudara

\begin{abstract}
Breast cancer is the highest cause of death in women. Objectives: To determined the picture of INVR score on CINV in Breast Cancer in M.Djamil General Hospital Padang. Methods:This was a quantitative descriptive study using medical record data. The nineteen patients were diagnosed with breast cancer in the Chemotherapy Department Dr. M. Djamil Padang in 2019. Results: The majority of patients were the elderly (42.1\%), high confidence (68.4\%), staging (63.4\%) and the second chemotherapy cycle (21.4\%). Measurement of the average score of nausea and vomiting done 72 hours or 6 times the measurement. Table 2 shows the average nausea of vomiting in the intervention group highest in the 60 hour measurement (21.00) with a min-max value (15-28) and the lowest in the 72 hour measurement (18.00) with a min-max value (3-22). Conclusion: The INVR score has decreased but has again increased.
\end{abstract}

Keywords: breast cancer, CINV, INVR

Affiliasi penulis: 1. RSU Mayjen H.A Thalib Kerinci, Indonesia 2. Rumah Sakit Universitas Andalas, Padang, Indonesia. 3. Fakultas Keperawatan, Universitas Andalas, Padang, Indonesia. Korespondensi: Wella Juartika, Email:Wella_juartika@yahoo.com, Telp:085379042192

\section{PENDAHULUAN}

Kanker payudara merupakan penyebab kematian tertinggi pada wanita. Menurut WHO jumlah penderita kanker payudara sebanyak 522.000 jiwa pada tahun 2012, terjadi peningkatan pada tahun 2015 menjadi sebanyak 571.000 jiwa. $^{1}$
Negara maju dengan angka kejadian tertinggi yaitu Amerika Serikat pada 2017 diperkirakan ada 252.710 kasus baru dan sekitar 40.610 wanita diperkirakan meninggal akibat kanker payudara. ${ }^{2}$ Indonesia juga menjadi negara yang menyumbang jumlah penderita sebanyak 61.682 orang, salah satunya daerah Sumatra Barat 2.285 orang. $^{3}$

Kanker payudara memerlukan beberapa tindakan salah satunya adalah kemoterapi. Kemoterapi merupakan tindakan yang mempunyai beberapa efek samping dan terbanyak keluhan yang 
dirasakan adalah mual muntah. Mual dan muntah yang diinduksi kemoterapi atau biasa disebut CINV memiliki efek buruk yang signifikan terhadap kesehatan pasien, termasuk dehidrasi, penurunan berat badan, gangguan metabolisme, dan penundaan atau penghentian kemoterapi, serta efek negatif terhadap kualitas hidup dan fungsi sehari-hari. ${ }^{4}$

Faktor yang berhubungan dengan pasien terkait peningkatan risiko emesis setelah menjalani terapi termasuk usia yang lebih muda ( $<50$ tahun), gen wanita, konsumsi alkohol yang rendah ( $\leq 44 \mathrm{~g} /$ minggu), dan riwayat motion sickness atau mual selama kehamilan. Tingkat etogenisitas rejimen kemoterapi ditentukan oleh emetogenisitas obat intrinsik dan dosis kemoterapi, dan, tanpa adanya terapi antiemetik, telah diklasifikasikan ke dalam kelompok risiko emetik: tinggi, sedang, rendah, dan minimal. ${ }^{5}$

Dampak apabila mual muntah terjadi berkepanjangan di khawatirkan akan muncul kondisi yang membahayakan yakni dehidrasi, perburukan status nutrisi, kualitas hidup menurun dan fungsi fisik, ${ }^{6}$ gangguan jadwal perawatan $(20 \%$ menunda pengobatan), penurunan kepatuhan, $30-40 \%$ pasien melaporkan mual yang tidak terkontrol dan muntah sering mengalami rawat inap, peningkatan biaya perawatan dan hilangnya hari kerja. ${ }^{7,8}$ Sejalan dengan penelitian Clark et al (2018) yang mengatakan masih ada $20 \%$ pasien mengalami perubahan kemoterapi karena CINV dan melaporkan kunjungan ke gawat darurat karena CINV yang tidak terkontrol. ${ }^{5}$

\section{METODE}

Penelitian ini adalah studi deskriptif kuantitatif dengan desain cross sectional study yang dilaksanakan di Bagian Kemoterapi RSUP Dr. M. Djamil Padang pada Februari 2019 - Maret 2019.

Sampel penelitian adalah seluruh pasien kanker payudara yang terdaftar di Bagian Kemoterapi RSUP Dr. M. Djamil Padang periode Januari 2016 Desember 2018 yang tercatat pada rekam medis dan memenuhi kriteria inklusi dan eksklusi. Kriteria Inklusi: pasien berusia di atas 26-55 tahun, kooperatif, mengalami CINV akut atau tertunda, Mampu mengenal tempat, orang dan waktu, Pasien mampu menulis maupun membaca, menggunakan obat kemoterapi doxorubicin via intravena, Pasien yang berada di kota padang, hal ini untuk memudahkan pemantauan serta observasi, Menggunakan antiemetik minimal Ondasentron, dexametasone dan ranitidin. Kriteria Eksklusi: penderita kanker lain, mengalami vertigo atau pusing, mengkonsumsi alkohol, riwayat motion sickness dan kecemasan.

Besar sampel minimal dihitung dengan menggunakan rumus untuk penelitian deskriptif kategorik, didapatkan sampel minimal yang dibutuhkan untuk penelitian ini sebesar 19 orang.

Alur penelitian dimulai dengan mengambil data nomor rekam medis pasien kanker payudara di bagian Kemoterapi RSUP Dr. M. Djamil Padang. Data-data yang diperlukan yaitu usia pasien, pendidikan, stadium,dan siklus kemoterapi. Pada masing-masing data pasien dilakukan pemilihan subjek yang memenuhi kriteria inklusi dan eksklusi sampel dilanjutkan dengan mengolah dan menganalasis data. Data skor mual muntah di gunakan kuesioner INVR rhodes.

\section{HASIL}

Distribusi frekuensi karakteristik responden berdasarkan usia, pendidikan, stadium dan siklus kemoterapi

Tabel 1. Distribusi frekuensi karakteristik responden berdasarkan usia, pendidikan, stadium dan siklus kemoterapi

\begin{tabular}{llcc}
\hline & Karakteristik & $\mathbf{f}$ & $\%$ \\
\hline Usia & Dewasa Awal & 6 & 31,6 \\
& Dewasa Akhir & 5 & 26,3 \\
Pendidikan & Lansia Awal & 8 & 42,1 \\
& Rendah & 6 & 31,6 \\
Stadium & Tinggi & 13 & 68,4 \\
\multirow{3}{*}{ Siklus } & II & 7 & 36,8 \\
Kemoterapi & III & 12 & 63,2 \\
& 1 & 3 & 15,8 \\
& 3 & 4 & 21,1 \\
& 4 & 3 & 15,8 \\
& 5 & 3 & 15,8 \\
& 6 & 3 & 15,8 \\
& & 3 & 15,8 \\
\hline
\end{tabular}


Distribusi pasien berdasarkan usia, pendidikan, stadium dan siklus kemoterapi dapat dilihat pada Tabel 1. Penelitian ini lebih banyak ditemukan pada usia lansia awal 8 orang (42,1\%). Pada pendidikan ditemukan lebih dari separuh dengan pendidikan tinggi 13 orang $(68,4 \%)$. Berdasarkan stadium lebih dari separoh pada stadium III yaitu 12 orang $(63,2 \%)$. Berdasarkan siklus kemoterapi

\section{Rerata skor mual muntah diinduksi kemoterapi pada pasien kanker payudara di RSUP M. Djamil Padang}

Pengukuran skor mual muntah di lakukan 72 jam atau 6 kali pengukuran. Tabel 2 menunjukkan median mual muntah pada kelompok intervensi tertinggi pada pengukuran 60 jam $(21,00)$ dengan nilai min-mak (15-28) dan terendah pada pengukuran 72 jam $(18,00)$ dengan nilai min-mak (3-22).

Tabel 2. Rerata skor mual muntah pengukuran 12 jam sampai dengan 72 jam pasien kanker payudara di RSUP Dr. M. Djamil Padang ( $\mathrm{n}=19)$

\begin{tabular}{ccc}
\hline Pengukuran & Median & Minimal-Maksimal \\
\hline 12 Jam & 20,00 & $12-25$ \\
24 Jam & 20,00 & $11-26$ \\
36 Jam & 19,00 & $15-22$ \\
48 Jam & 19,00 & $14-26$ \\
60 Jam & 21,00 & $15-28$ \\
72 Jam & 18,00 & $3-22$ \\
\hline
\end{tabular}

\section{PEMBAHASAN}

Berdasarkan penelitian mengenai gambaran skor mual muntah setelah kemoterapi di Bagian Kemoterapi RSUP Dr. M. Djamil Padang tahun Februari - Maret 2019 terdapat 19 kasus kanker payudara yang memenuhi kriteria inklusi.

Wanita lebih rentan terkena kanker payudara. Kanker payudara di pengaruhi oleh hormon dan juga genetik. Pada wanita sering terjadi pada usia lansia awal. Penelitian yang dilakukan oleh Laurentiis et al (2018) menemukan bahwa usia terjadi pada usia 3478 tahun. $^{9}$

Kondisi ini sejalan dengan hasil penelitian dilakukan oleh Syarif dimana mual muntah pada pasien setelah kemoterapi dan ditemukan rata-rata usia 49 tahun atau sama dengan lansia awal. ${ }^{10}$ Didukung oleh penelitian Molassiotis dan Russell
(2014) dimana melakukan tindakan yang bertujuan untuk melakukan manajemen mual muntah pada fase acute dan delayed, penelitian tersebut melaporkan data usia responden berada pada rata-rata usia 49 tahun (lansia awal). ${ }^{11}$

Hasil dari penelitian yang dilakukan Rahmatya et al (2015) melihat hubungan usia dengan gambaran klinik patologi kanker payudara di Bagian Bedah RSUP M.Djamil Padang. Pada penelitiannya ditemukan sebagian besar penderita berusia lebih dari 40 tahun $(78,3 \%)$ atau rata-rata berusia 46,87 tahun. ${ }^{12}$

Faktor resiko kejadian kanker payudara salah satunya adalah faktor usia. Usia $<65$ tahun dan dapat meningkat hingga usia 80 tahun. Faktor lainnya yang berhubungan dengan usia yaitu riwayat pribadi kanker payudara stadium awal di usia $<40$ tahun. $^{2}$

Usia merupakan masalah utama dimana responden dengan usia yang lebih tua lebih lama terpajan oleh sel kanker atau karsinogen dari pada responden dengan usia lebih muda. Sel-sel yang menua disemua organ dan khususnya dijaringan payudara kehilangan sebagian kemampuannya untuk memperbaiki kerusakan DNA. Penumpukan kesalahan yang dilakukan oleh DNA dapat menyebabkan peluang keganasan kanker payudara semakin meningkat dan bertambah. Sebanyak $88 \%$ terjadi pada wanita diatas usia 55 tahun. Maka bertambahnya usia sangat terkait dengan terjadinya kanker payudara. Sehingga, usia tetap merupakan faktor risiko independen nomor satu yang terkait dengan kanker payudara. Penuaan adalah kebutuhan yang tidak dapat diubah. ${ }^{11}$

Masalah usia juga menjadi masalah efek samping yang diterima oleh responden yang menerima kemoterapi. Salah satunya adalah mual muntah setelah kemoterapi atau CINV. Faktor resiko mual muntah juga dipengaruhi oleh usia. Hal ini didukungpenelitian yang dilakukan oleh Grunberg melakukan penelitian pada responden dengan rentang usia 24-83 tahun. Hasil penelitian ini mengungkapkan usia $<60$ tahun merupakan risiko CINV yang signifikan yan terkait pada jenis fase akut dan tertunda. Penggunaan antagonis reseptor 5-HT3 generasi pertama tanpa antagonis reseptor NK-1 dinyatakan factor resiko penting. Usia mempengaruhi 
neurotransmitter lansung. Hal ini adanya pengaruh dari ketidaknyamanan dan zat opiat yang terkandung pada beberapa obat kemoterapi sehingga memicu peningkatan ransangan 5 - $\mathrm{HT} 3 .{ }^{13}$

Penelitian Sari et al (2015) melakukan penelitian dengan jumlah sampel 15 responden. Hasil yang didapatkan adalah pasien dengan stadium III merupakan pasien terbanyak yang ditemukan yaitu $46,7 \% .^{14}$

Kanker payudara stadium III adalah tumor yang lebih besar atau dapat tumbuh pada jaringan di dekatnya (kulit diatas payudara atau otot di bawahnya) atau telah menyebar ke banyak kelenjar getah bening di sekitarnya. Salah satu treatment yang dilakukan pada stadium ini dimulai dengan terapi neoadjuvant atau sebelum pembedahan dengan kemoterapi. Kemoterapi bertujuan untuk mengecilkan ukuran tumor. ${ }^{1}$ Stadium awal gejala kanker payudara kurang dirasakan, sehingga tidak adanya deteksi dini. Akibatnya banyak sekali ditemukan pasien terlambat bahkan takut untuk memeriksakan kesehatan.

Penelitian ini sejalan dengan Rapoport (2017) dimana CINV tertunda sangat komplek. Reflek yang dialami melibatkan jalur luaran dari kedua sistem saraf pusat dan perifer. Masalah ini akan selalu muncul saat pasien melakukan kemoterapi. ${ }^{15}$

Pengukuran rerata skor mual muntah di lakukan 72 jam atau 6 kali pengukuran. Tabel 2 menunjukkan rata-rata mual muntah pada kelompok intervensi tertinggi pada pengukuran 60 jam $(21,00)$ dengan nilai min-mak (15-28) dan terendah pada pengukuran 72 jam $(18,00)$ dengan nilai min-mak (322).

Setelah terpapar agen kemoterapi, sel-sel enterochromafin yang rusak di saluran pencernaan melepaskan serotonin yang kemudian berikatan dengan reseptor 5-HT3 pada aferen vagal terdekat di perut. ${ }^{4}$ Serat saraf aferen mentransmisikan input sensorik dari saluran pencernaan ke pusat emetik dari saluran pencernaan. otak. Pusat emetik terdiri dari jaringan neuron yang terorganisir secara longgar di batang otak yang menerima sinyal tidak hanya dari saluran pencernaan tetapi juga dari struktur lain, seperti zona pemicu kemoterapi di area postrema. Sinyal-sinyal sensorik ini dikonsolidasikan di pusat emetik, yang mengarah ke generasi sinyal eferen ke otot perut dan diafragma dan emesis selanjutnya. Kemoreseptor daerah postrema terletak di luar sawar darah-otak dan dapat langsung diaktifkan oleh agen kemoterapi juga, memicu emesis. ${ }^{16}$

Zat neurotransmitter $P$, yang hadir dalam sistem saraf perifer dan sentral, juga dilepaskan setelah terpapar kemoterapi dan mengikat reseptor NK-1. Sementara serotonin adalah mediator utama dari sinyal emetik dari saluran pencernaan, zat $P$ tampaknya paling umum mengikat reseptor NK-1 dalam sistem saraf pusat dan mendapatkan sinyal langsung ke zona pemicu kemoterapi dan pusat emetik otak, yang mengarah ke emesis tertunda. Zat $\mathrm{P}$ juga bertindak dalam saluran pencernaan, berpotensi memainkan peran tambahan dalam CINV akut. Crosstalk antara reseptor 5-HT3 dan NK-1 juga telah dihipotesiskan, dan dapat menjelaskan beberapa perbedaan di antara obat-obatan. Aktivasi salah satu kemoreseptor ini dapat membuat peka saraf vagus terhadap stimulasi jalur reseptor lainnya dan menghasilkan CINV yang berkepanjangan. ${ }^{17}$

Kemajuan substansial dalam profilaksis CINV sudah ada, tetapi sebanyak $40 \%$ pasien dengan kanker masih mengalami mual, muntah, atau keduanya setelah diterimanya kemoterapi. ${ }^{18}$ Ada kebutuhan yang jelas untuk perbaikan lebih lanjut dalam pengelolaan efek samping yang mengganggu ini. Mungkin kebutuhan terbesar yang belum terpenuhi di CINV adalah kurangnya kontrol mual lengkap. ${ }^{19}$

Sebuah studi pasien dengan kanker payudara yang menerima kemoterapi berbasis antrasiklin/ siklofosfamid menunjukkan bahwa $71 \%$ pasien mengalami mual walaupun diresepkan terapi antiemetik berbasis pedoman dan pasien secara konsisten menilai mual lebih dari muntah sebagai efek samping terburuk yang terkait dengan kemoterapi. ${ }^{6}$ Mual dan muntah sering dianggap sebagai gejala yang menyatu, fisiologi yang tepat dan faktor risiko yang berkontribusi terhadap mual kurang dipahami dan banyak agen antiemetik yang ada saat ini tidak banyak membantu meredakan mual yang diinduksi kemoterapi. ${ }^{20}$ Mual hanya dapat diukur secara subyektif dan mungkin tidak dilaporkan oleh pasien dan diremehkan oleh dokter. ${ }^{4}$ 


\section{SIMPULAN}

Pada umumnya penderita datang berobat pada stadium lanjut (II dan III). Terjadi penurunan dari pengukuran dari jam12 jam sampai 72 jam.

\section{SARAN}

Diharapkan kepada perawat kemoterapi memberikan edukasi dan pemahaman tentang mual muntah setelah kemoterapi, agar pasien dan keluarga tidak berhenti melakukan terapi sesuai dengan target yang direncanakan.

\section{UCAPAN TERIMA KASIH}

Terima kasih kepada semua pihak yang telah membantu dalam pelaksanaan penelitian. Kepada Direktur Umum RSUP Dr. M Djamil Padang yang telah memberikan izin melaksanakan penelitian dan kepada staf bagian rekam medik yang telah membantu penulis dalam melaksanakan penelitian.

\section{DAFTAR PUSTAKA}

1. World Health Organization (WHO). Cancer (diunduh 20 Agustus 2019). Tersedia dari: http://www.who.int/cancer/en/.

2. American Cancer Society (ACS). Breast cancer facts \& figures 2017-2018 (diunduh 20 Agustus 2019). Tersedia dari: https://www.cancer.org/ research/cancer-facts-statistics/all-cancer-factsfigures/cancer-facts-figures-2018.html. Published 2018.

3. Kementerian Kesehatan RI (Kemenkes RI). Riset Kesehatan Dasar (RISKESDAS) 2013. Jakarta: Kemenkes RI; 2013.

4. Aapro M. Pathophysiology of nausea and vomiting. London: Springer Healthcare; 2015. Tersedia dari: http://ime.springerhealthcare. com/wp-content/uploads/Pathophysiology _CINV.pdf.

5. Clark SR, Afronti ML, Rittenverg CN. Chemotherapy - induced nausea and vomiting (CINV) and adherence to antiemetic guidelines: results of a survey of oncology nurses. Support Care Cancer. 2018;26:557-64.

6. Isenring L. Chemotherapy-Induced nausea and vomiting: a narrative review to inform dietetics practice. Jurnal Academia Nutrient Diet. 2016;116(5):819-27.

7. Perry MC, Doll DC. The chemotherapy source book. USA: Wolters Kluwer; 2012.

8. Jhaverikenar D, Salahudeen AK. Onconephrology: cancer, chemotherapy and the kidney. USA: Springer; 2015.

9. Laurentiis $\mathrm{M}$, Bonfadini $\mathrm{C}$, Lorusso $\mathrm{V}$, et al. Incidence of nausea and vomiting in breast cancer patients treated with anthracycline plus cyclophosphamide-based chemotherapy regimens in Italy: NAVY observational study. Support Care Cancer. 2018:1-3.

10. Syarif $\mathrm{H}$. Pengaruh terapi akupresure terhadap mual muntah akibat kemoterapi pada pasien kanker; A randomized clinical trial. 2009 [tesis]. Depok: Fakultas Keperawatan, Universitas Indonesia; 2009.

11. Molassiotis A, Russell W. The effectiveness of acupressure for the control and management of chemotherapy-related acute and delayed nausea: a randomized controlled trial. Jurnal Pain Symptom Managed. 2014;47(1):12-25.

12. Rahmatya $A$, Khambri $D$, Mulyani $H$. Hubungan usia dengan gambaran klinikpatologi kanker payudara di bagian bedah RSUP Dr. M.Djamil Padang. Jurnal Kesehatan Andalas. 2015; 4 (2): 478-84.

13. Grunberg S. Patient-centered management of chemotherapy-induced nausea and vomiting. cancer control. 2012;192 (Suplement):10, 234-8.

14. Sari RI, Hartoyo M, Wulandari. Pengaruh aromaterapi peppermint terhadap penurunan mual muntah akut pada pasien yang menjalani kemoterapi di SMC RS Telogorejo. Jurnal IImu Keperawatan dan Kebidanan. 2015;1:12-8.

15. Rapoport BL. Delayed chemotherapy-induced nausea and vomiting: pathogenesis, incidence , and current management. Front Pharmacol. 2017;8(January):1-10.

16. Hilarius DL, Kloeg PH, Van Der Wall E, Van Den Heuvel JJG, Gundy CM, Aaronson NK. Chemotherapy-induced nausea and vomiting in daily clinical practice: A community hospitalbased study. Support Care Cancer. 2012;20(1):107-17. 
17. Navari RM. 5-HT3 receptors as important mediators of nausea and vomiting due to chemotherapy. Biochim Biophys Acta. 2015;1848(10 Pt B):2738-46.

18. Feyer $\mathrm{P}$, Jordan $\mathrm{K}$. Update and new trends in antiemetic therapy: The continuing need for novel therapies. Ann Oncol. 2011;22(1):30-8.
19. Coleman EA, Coon SK, Lockhart K, et al. Effect of certification in oncology nursing on nursingsensitive outcomes. Clinical Journal Oncology Nursing. 2009;12:234-8.

20. Gordon P, Legrand SB, Walsh D. Nausea and vomiting in advanced cancer. Europhea Journal Pharmacology. 2014;13:123-6. 